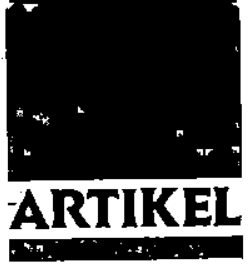

Saut P. Panjaitan

\title{
Makna dan Peranan Freies Ermessen dalam Hukum Administrasi Negara.
}

\section{A. Pendahuluan}

Perkembangan konsep "negara. hukum ${ }^{\prime 1)}$ pada saat ini telah menghasilkan suatu konsep negara hukum kesejahteraan (social service state; welvaarstaat). Dalam suatu negara hukum yang demikian ini, tugas negara sebagai servis publik adalah menyelenggarakan dan mengupayakan suatu kesejahteraan sosial (yang oleh Prof. Lemaire disebutnya dengan : "bestuurszorg") bagi masyarakatnya. Jadi, tugas negara bukan hanya sebagai pemelihara keamanan dan ketertiban saja. Oleh karena itu maka negara melakukan campur tangan. hampir di setiap sektor kehidupan masyarakat.

Salah satu alasan nyata bagi pertumbuhan kekuasaan administrasi negara di negara-negara demokrasi modern adalah seiring dengan pudarnya falsafah "laissez faire" dan meningkatnya peranan negara dalam bidang sosial-ekonomi. Seperti diketahui, "laissez faire" menginginkan sedikitnya peranan negara dalam mengontrol usaha-usaha pribadi dalam masyrakat dan besarnya peranari individu dalam melakukan kebebasan berkontrak. Falsafah ini ternyata justeru menimbulkan penderitaan bagi manusia, karena mengakibatkan terjadinya eksploatasi oleh yang kuat terhadap kelompok orangorang yang lemah. Oleh karena itu maka timbul pemikiran-pemikiran mengenai konsep negara kesejahteraan.

1. Perkembangan tersebut dimulai dari konsep negara "nomoi" (negara hukum) dari Plato, Polizeistaat, nachtwakerstaat/negara hukum liberal/negara hukum formal (Kant, Fichte, dan Stahl), dan welvaarstaat/negara hukum material/sociale verzorigingsstaat/social service state di Eropa Kontinental. Sedangkan di Anglo-Saxon berkembang konsep "rule of lawn dari Dicey.

Untuk jelasnya lihat : $O$. Notohamidjojo dalam "Makna Negara Hukum", 1970, hlm. 11-35; Sudarga Gautama dalam "Pengertian Tentang Negana Hukum", 1973; Padmo Wahjono dalam "Indonesia Negara Berdasarkan Atas Hukum", 1983; serta Soerjono Soekanto dalam "Beberapa Permasalahan Hukum Dalam Kerangka Pembangunan Di Indonesia ${ }^{*}, 1976$, hlm. 49-78. 
Friedmann 2) dalam bukunya "The Rule of Law And The Welfare State" menyebutkan adanya lima fungsi dari negara kesejahteraan, yaitu sebagai protector, provider, regulator, entrepeneur, dan arbitrator.

Dalam rangka menjalankan fungsi tersebut, negara harus memiliki lembaga-lembaga dan standar perlakuan yang menjamin terselenggaranya kesejahteraan sosial. Sebagai wakil rakyat secara keseluruhan, negara harus mengatur dan menjalankan keadilan di antara sektor-sektor masyarakat yang berbeda. Lembaga dan standar perlakuan tadi dimaksudkan untuk menjamin terselenggaranya keadilan dan kesejahteraan masyarakat, dan hal tersebut diatur melalui hukum, khususnya Hukum Administrasi Negara.

Perkembangan konsep negara hukum seperti telah disinggung pada awal tulisan ini, erat kaitannya dengan peranan Hukum Administrasi Negara di dalamnya. Pada "polizeistaat" boleh dikatakan belum berkembang Hukum Adminstrasi Negara, barulah pada "nachtwakerstaat" Hukum Administrasi Negara mulai muncul, meskipun sangat terbatas. Pada "welvaarstaat" peranan Hukum Administrasi Negara menjadi semakin luas dan dominan. Hal ini menunjukkan semakin aktifnya negara terlibat dan melakukan campur tangan dalam setiap aspek kehidupan masyarakat. Adalah sukar membayangkan suatu negara modern saat ini tanpa adanya Hukum Administrasi Negara di dalamnya.

Akan tetapi mengingat sedemikian luasnya aspek kehidupan sosial dan kesejahteraan masyarakat yang digeluti itu, maka sudah barang tentu tidak setiap permasalahan yang dihadapi dan tindakan yang akan diambil oleh adminstrasi negara telah tersedia aturannya. Keadaan seperti ini membawa adminstrasi negara kepada suatu konsekuensi khusus, yaitu memerlukan kemerdekaan bertindak atas inisiatif dan kebijaksanaannya sendiri, terutama dalam penyelesaian soal-soal genting yang timbul dengan sekonyong-konyong dan yang peraturan penyelesaiannya belum ada. Kemerdekaan bertindak atas inisiatif dan kebijaksanaan sendiri ini, dalam Hukum Administrasi Negara tersebut dengan "pouvoir discretionnaire" atau "freies ermessen".3)

Adanya "freies ermessen" bukannya tidak menimbulkan masalah, karena kemungkinan terjadinya pelanggaran terhadap hak warga negara semakin besar, yang tercermin melalui "onrectmatigeoverheidsdaad", "detournement de pouvoir" atau "ultra vires", ataupun "abus de droit".

2. Dikutip dari MP. Jain dalam ${ }^{n}$ Development of Administrative Law in Malaysia Since Merdeka" yang dimuat dalam "The Malayan Law Journal Supplement", (1977) 2 MLJ,ms.ii. Lihat pula Sunarjati Hartono dalam "Apakah The Rule of Law Itu?", Alumni, Bandung, 1976.

3. Sjachran Basah. Eksistensi Dan Tolok Ukur Badan Peradilan Administrasi Di Indonesia. Alumni, Bandung, 1985, hlm. 12. Lihat juga E.Utrecht dalam "Pengantar Hukum Administrasi Negara Indonesia", FH UNPAD, 1960, hlm. 23. 
Di sinilah arti pentingnya peranan Hukum Administrasi Negara, sebab di satu pihak ia dipergunakan untuk memungkinkan agar administrasi negara dapat menjalankan fungsinya (sebagai landasan kerja), tetapi di lain pihak Hukum Administrasi Negara diperlukan untuk melindungi warga masyarakat terhadap sikap tindak administrasi negara dan untuk melindungi administrasi negara itu sendiri. ${ }^{4)}$

Agar "freies ermessen" yang ada pada administrasi negara tersebut tidak disalah gunakan, maka diperlukan adanya tolok ukur pembatasan terhadap penggunaannya. Dengan perkataan lain ada batas toleransi yang mesti dipenuhi oleh administrasi negara dalam menggunakan "freies ermessen" ini.

Berdasarkan uraian di atas nyatalah bahwa "freies ermessen" mempunyai kedudukan yang cukup penting dalam Hukum Administrasi Negara, sehingga adanya kajian mengenai makna dan peranan "freies ermessen" dalam Hukum Administrasi Negara akan menjadi cukup penting pula.

\section{B. Pengertian Freies Ermessen}

Istilah "freies ermessen" berasal dari bahasa Jerman. Kata "freies" diturunkan dari kata "frei" dan "freie" yang artinya : bebas, merdeka, tidak terikat, lepas, dan orang bebas. Sedangkan kata "ermessen" mengandung arti mempertimbangkan, menilai, menduga, penilaian, pertimbangan, dan keputusan.5) Jadi secara etimologis, "freies ermessen" dapat diartikan sebagai "orang yang bebas mempertimbangkan, bebas menilai, bebas menduga, dan bebas mengambil keputusan".

Selain itu istilah "freies ermessen" ini sepadan dengan kata "discretionair", yang artinya menurut kebijaksanaan, dan sebagai kata sifat, berarti : menurut wewenang atau kekuasaan yang tidak atau tidak seluruhnya terikat pada undangundang".6)

Dalam kepustakaan Ilmu Hukum Administrasi Negara telah banyak pakar yang memberikan batasan mengenai istilah ini. Prajudi Atmosudirdjo ${ }^{7)}$ mengatakan :

"....asas diskresi (discretie; freies ermessen), artinya, pejabat penguasa tidak boleh menolak mengambil keputusan dengan alasan 'tidak ada peraturannya', dan oleh karena itu diberi $k e$ bebasan untuk mengambil keputusan menurut pendapat sendiri asalkan tidak melanggar asas yuridiktas dan asas legalitas..."

4. Lihat Sjachran Basah dalam "Perlindungan Hukum Terhadap Sikap Tindak Administrasi Negara". Orasi Ilmiah pada Dies Natalis XXIX Unpad, Bandung, 24 September 1986, hlm. 4.

5. Adolf Heuken SJ. Kamus Jerman-Indonesia. Gramedia, Jakarta, 1987.

6. Fochema-Andreae. Kamus Istilah Hukum(Terjemahan Saleh Adiwinata, et.al.). Binacipta, Bandung, 1983, hlm. 145 dan hlm. 98.

7. Prajudi Atmosudirdjo. Hukum Administrasi Negara. Ghalia Indonesia, Jakarta, 1981, hlm. 85 . 
Senada dengan pendapat tersebut, Sjachran Basah ${ }^{8)}$ mengatakan bahwa diperlukannya "freies ermessen" oleh administrasi negara itu :

"....dimungkinkan oleh hukum agar dapat bertindak atas inisiatif sendiri,.... terutama dalam penyelesaian persoalan-persoalan penting yang timbul secara tiba-tiba. Dalam hal demikian, administrasi negara terpaksa bertindak cepat, membuat penyelesaian. Namun keputusankeputusan yang diambil untuk menyelesaikan masalah-masalah itu, harus dapat dipertanggung jawabkan."

Pada bagian lain dari buku tersebut "freies ermessen" itu diartikan sebagai "kebebasan bertindak dalam batasbatas tertentu"9) atau "keleluasaan dalam menentukan kebijakankebijakan melalui sikap tindak administrasi negara yang harus dapat dipertanggungjawábkan" ${ }^{\prime 10)}$

Amrah Muslimin ${ }^{11)}$ mengartikan "freies ermessen" sebagai "lapangan bergerak selaku kebijaksanaannya" atau "kebebasan kebijaksanaan".

Dari beberapa pendapat yang dikutip sebelumnya, pada hakikatnya tidak terdapat perbedaan yang prinsip, sebab inti hakikat yang dikandungnya adalah sama, yaitu adanya kebebasan bertindak bagi administrasi negara untuk menjalankan fungsinya secara dinamis guna menyelesaikan persoalan-persoalan penting yang mendesak, sedangkan aturan untuk itu belum ada.

Sehubungan dengan hal tersebut, Hans J.Wolf ${ }^{12)}$ dalam bukunya
"Verwaltungsrecht" jilid I, mengatakan bahwa "freies ermessen" tidak boleh diartikan secara berlebihan seakan-akan badan atau pejabat administrasi negara boleh bertindak sewenang-wenang atau tanpa dasar dan dengan dasar-dasar yang tidak jelas ataupun dengan pertimbangan yang subjektif-individual. Oleh karena itu, menurut Wolf, lebih baik jika dikatakan mereka bertindak berdasarkan kebijaksanaan. ${ }^{13)}$ Berdasarkan uraian tersebut maka sebaiknya pengertian "freies ermessen" ini diberikan arti yang netral sebagai :

"....power to choose between alternative courses of action" ${ }^{14}$

Berdasarkan uraian yang dikemukakan, maka penulis sampai pada suatu kesimpulan bahwa "freies ermessen" adalah : hlm. 151 .

8. Sjachran Basah. Eksistensi.....Op.cit,

9. Ibid. hlm. 219.

10. Sjachran Basah Perlindungan Hukum... Op.cit, hlm. 2.

11. Amrah Muslimin Beberapa Asas Dan Pengertian Pokok Tentang Administrasi Dan Hukum Administrasi. Alumni, Bandung, 1985, hlm. 73.

12. Dikutip dari Marcus Lukman dalam "Freies Ermessen Dalam Proses Perencanaan Dan Pelaksanaan Rencana Kota Di Kotamadya Pontianak". Thesis Magister Pada Fakultas Pascasarjana Unpad, tidak dipublisir, 1989, hlm. 145-146.

13. Ibid

14. S.A. de Smith Constitutional And Administrative Law Penguin Books, 5th edition, 1985.p. 597. 
"kebebasan atau keleluasaan bertindak administrasi negara yang dimungkinkän oleh hukum untuk bertindak atas inisiatifnya sendiri guna menyelesaikan persoalanpersoalan penting yang mendesak yang aturannya belum ada, dan tindakan tersebut harus dapat dipertanggungjawabkan".

Kebebasan bertindak administrasi. negara dimaksud bukan kebebasan dalam arti yang seluas-luasnya dan tanpa batas, melainkan tetap terikat kepada batas-batas tertentu yang diperkenankan oleh Hukum Administrasi Negara.

Sebagai konsekuensi diberikannya "freies ermessen" ini kepada administrasi negara, maka administrasi negara memiliki "pouvoir discretionaire" dan oleh karena itu ia dapat bertindak sebagai "vrij bestuur". Dalam kaitan ini, timbul kekhawatiran dari kaum legis bahwa hal tersebut bertentangan dengan asas legalitas, terutama prinsip "wetmatigeheid van bestuur", yang artinya semua perbuatan dalam pemerintahan itu harus berdasarkan pada wewenang yang diberikan oleh suatu peraturan perundang-undangan (baca : hukum tertulis).

Berkaitan dengan hal ini, Mr.DR.A.Q.C. TAK dalam bukunya "Overheidsbestuur en Privaatrecht" 15) menyatakan :

"Dalam kenyataannya memang ajaran 'wetmatigeheid van bestuur' itu suatu fiksi belaka.....kerap kali pemerintah berbuat sesuatu bukan berdasar pada ketentuan perundang-undangan, melainkan berdasar pada penggarisan-penggarisan atau petunjuk-petunjuk dari instansi atasannya. Dalam hal-hal lain, wewenang pemerintáh melakukan perbuatannya 'berdasarkan wewenang' yang tersebut dalam peraturan, tetapi kerap káli rumusan wewenang tersebut demikian samarsamar atau demikian luas, hingga praktis merupakan blanco volmacht... dan mereka yang menganut ajaran legistis tidak lagi banyak jumlahnya, dan umumnya sudah sesuai (menganut,"pen) teoriteori' 'rechtssouvereiniteit' yang beranggapan, bahwa penguasapun dalam melakukan perbuatanperbuatan tunduk pada hukum tertulis maupun tidak tertulis".

Berdasarkan kutipan di atas, secara tersirat TAK menolak ajaran "welvaarstaat", maka TAK dapat menerima adanya "vrij bestuur" ini, sepanjang hal tersebut tidak melanggar prinsip kedaulatan hukum (rechtssouvereiniteit), yang mengenal bukan saja hukum tertulis tetapi juga hukum tidak tertulis.

Penulis berpendapat bahwa memang dalam suatu negara kesejahteraan, prinsip "wetmatigeheid van bestuur" tidak dapat lagi dipertahankan secara kaku. Kenyataan ini didukung oleh fakta bahwa apabila prinsip ini dianut secara kaku, maka administrasi negara akan sulit mengantisipasi setiap perkembangan yang

15. Sebagaimana disadur oleh Indroharto dibawah judul "Pengawasan Terhadap Perbuatan-Perbuatan Dalam Pemeriniahan". Paper, tidak dipublisir, 1984, hlm. 13. 
terjadi dalam masyarakat, oleh karena setiap saat harus menunggu peraturan perundang-undangannya terlebih dahulu. Pada sisi lain, badan legislatif pun tidak dapat sepenuhnya menangani semua perkembangan yang terjadi, disebabkan beberapa kelemahan yang ada padanya seperti yang dikatakan Sidney Low ${ }^{16}$; bahwa anggota badan legislatif terdiri dari "amatir-amatir" yang tidak sepenuhnya menguasai persoalan, disamping itu besarnya jumlah anggota legislatif pada akhirnya akan menyulitkan dalam mengambil suatu keputusan.

Itulah sebabnya dalam suatu negara modern, peranan administrasi negara (eksekutif) sebagai penyelenggara pemerintahan menjadi lebih dominan dibandingkan dengan peranan legislatif. Sehingga administrasi negara tidak hanya sekedar melaksanakan undang-undang (legisme), melainkan demi terselénggaranya negara hukum dalam arti materil, memerlukan adanya "freies ermessen".

Dengan diberikannya "freies ermessen" maka administrasi negara tidak dapat lagi menunggu perintah dari badan-badan kenegaraan yang diserahi fungsi legislatif., Dalam hal demikian administrasi negaralah yang membuat peraturan penyelesaian yang diperlukan itu. Ini berarti bahwa sebagian kekuasaan yang dipegang oleh badan legislatif, diserahkan kepada administrasi negara sebagai eksekutif. Hal ini menjadi kenyataan di setiap "welfarestate"17) Dalam hal ini telah terjadi apa yang dalam kepustakaan dikenal dengan "delegatie van wetgeving bevoegheid".
Dari uraian yang tèlah dikemukakan sebelumnya menúnjukkan cukup peritingnya kegunaan "freies ermessen" dälam negara hukum materil, karena ternyata di dalamnya terkait banyak aspek dan dimensi yang kesemuanya berpolar pada dua dimensi, yaitu kekuasaan (dalam wujud "pouvoir discretionnaire", "vrij bestuur", "delegatie van wetgeving bevoegheid") dan hukum" (dalam wujud "asas legalitas", prinsip "wetmatigeheid van ven bestuur", dan "rechtssouvereiniteit").

\section{Peranan Freies Ermessen dálam HAN}

Dengan adanya "freies ermessen" maka administrasi negara dapat menjalankan fungsinya secara dinamis dalam menyelenggarakan kepentingan umum, sehingga dalam menghadapi hal-hal yang sifatnya penting dan mendesak yang aturannya belum tersedia untuk itu, administrasi negara atas inisiatifnya sendiri dapat langsung bertindak tanpa menunggu instruksi lagi. Jadi, administrasi negara dapat langsung bertindak dengan berpijak kepadá asas kebijaksanaan ${ }^{18)}$. Dengan demikian sifatnya adalah spontan.

Dengan demikian "freies ermessen" merupakan kekecualian terhadap asas legalitas dalam arti yạng sempit

16. Periksa Amrah Muslimin. Op.cit, hlm. 69.

17. E. Utrecht, Op.cit. hlm. 24.

18. Periksa-Kuntjoro Purbopranoto dalam "Beberapa Catatan Hukum Tata Pemerintahan Dan Peradilan Administrasi Negara". Alumni, Bandung, 1978, hlm. 35. 
dengan prinsip "wetmatigeheid van bestuur"-nya. Hal ini bukan berarti dikesampingkannya sama sekali asas legalitas, karena sikap-tindak administrasi negara harus dapat diuji berdasarkan peraturan perundangundangan lainnya yang lebih tinggi ataupun berdasarkan ketentuan hukum yang tidak tertulis. Dalam hal ini tetap dipergunakan asas legalitas, hanya saja dalam pengertian yang lebih luas dan fleksibel yang tidak saja berdasarkan pada peraturan perundang-undangan yang tertulis tetapi juga berdasarkan pada ketentuan hukum yang tidak tertulis, seperti misalnya "algemene beginselen van vehoorlijk bestuur". Hal ini tercermin melalui rumusan penulis di muka yang tercakup dalam kata-kata "dapat dipertanggungjawabkan".

Sehubungan dengan hal ini, Prajudi Atmosudirdjo ${ }^{19)}$ menyatakan :

"Diskresi diperlakukan sebagai pelengkap dari pada asas legalitas, yaitu asas hukum yang menyatakan bahwa setiap tindak atau perbuatan administrasi negara harus berdasarkan ketentuan undang-undang" (garis bawah oleh penulis)

Melihat pada perkembangan yang semakin cepat dalam masyarakat pada suatu negara modern pada saat ini, maka dituntut pula kesiapan administrasi negera untuk mengantisipasi perkembangan yang terjadi itu. Dalam hal ini, sudah barang tentu asas legalitas (dalam arti "wetmatigeheid van bestuur") tidak dapat lagi dipertahankan secara kaku. Sebab dalam keadaan seperti ini, administrasi negara bukan hanya terompet dari suatu peraturan perundang-undangan, melainkan dalam melaksanakan tugasnya itu mereka wajib bersikap aktif . demi terselenggarakanya tugas-tugas servis publik, yang kesemuanya itu tidak dapat ditampung oleh hukum yang tertulis saja. Oleh karenanya maka diperlukan "freies ermessen".

Apabila kita hubungkan dengan pendapat Sjachran Basah, ${ }^{20)}$ maka implementasi "freies ermessen" melalui sikap tindak administrasi negara ini dapat berwujud :

a. membentuk peraturan perundang-undangan di bawah undang-undang yang secara materil mengikat umum;

b. mengeluarkan "beschikking" yang bersifat konkret, final, dan individual;

c. melakukan tindak administrasi yang nyata dan aktif;

d. menjalankan fungsi peradilan, terutama dalam hal "keberatan" dan "banding administrasi".

Bertitiktolak dari uraian tersebut maka diperlukannya "freies ermessen" dalam Hukum Administrasi Negara" dapat dimanfaatkan untuk mengisi celah atau kekosongan hukum (rechtsvacuum). Dengan demikian dapat dikatakan bahwa "freies ermessen" berperan dalam mengisi, melengkapi, dan mengembangkan Hukum Administrasi Negara.

19. Prajudi Atmosudirdjo, Op.cit, hlm. 77-78.

20. Lihat : Sjachran Basah Perlindungan... Op.cit, hlm. 5 


\section{Kepustakäan}

Amrah Muslimini, Beberapa Asas Dan Pénger'tian "Pokok' Tentang Administrasi Dan Hukum Administrasi, Alumni Bandung, 1985.

De Smith, S.A., Constitutional And Administrative Law, Penguin Books, Sth Edition, 1985 .

Indroharto, Pengawasan Terhadap PerbuatanPerbuatan Dalam Pemerintahan, Saduran atas buku Mr. DR. A.Q.C. TAK, yang berjudul "Overheidsbestuur en Privaatrecht", tidak dipublisir, 1984.

Jain MP, Development of Administrative Law In Malaysia Since Merdeka, dimuat dalam "The Malaya Law Journal Supplement", 1977.

Kuntjoro Purbopranoto, Beberapa Catatan Hukum Tata Pemerintahan Dan Peradilan Administrasi Negara, Alumni Bandung, 1978.

Marcus Lukman, Freies Ermessen Dalam Proses Perencanaan Dan Pelaksanaan Rencana Kota di Kotamadya Pontianak, Tesis Magister pada Fakultas Pascasarjada UNPAD, tidak dipublisir, 1989.

Notohamidjojo,O.,' Makna Negara Hukum, BPK, Jakartà, 1978.

Padmo Wahyono, Indonesia Negara Berdasarkan Atas Hukum, Ghalaia Indonesia, Jakarta, 1983.
Prajudi 'Atmosudirdjo,' Hukum Administraśi $\therefore$ Negara,-Ghalia Indonesia, Jakartá, 1981. Sùdargo Gautama, Pengertian Tentang Negara Hukum,'Alumni, Bandung, 1973.

Soejono Soekanto, Beberapa Permasalahan Hukum Dalam Kerangka Pembangunan di Indonesia, UI-Press, Jakārta, 1978. ,

Sunaryati Hartono, Apakah The Rule of Law. Itu, Alumni, , Bandung, 1976.

Sjachran Basah, Eksistensi Dan Tolok Ukur Badan Peradilan Administrasi di Indonesia, Alumni, Bandung, 1985. , Perlindungan Hukum Terhadap Sikap Tindak Administrasi Negara, Orasi Ilmiah pada Dies Natalis UNPAD XXIXX, 24 September 1986.

$\therefore$ - B._. Beberapa Permasalahan Pokok Sebelum Realisasi Efektif Pengadilan Administrasi, Dimuat dalam "Bunga Rampai HTN,dan HAN", FH UII, 1987.

Utrecht, E., Pengantar Hukum Administrasi Negara Indonesia, FH UNPAD, 1960.

\section{Kamus :}

1. Fockema-Andreae, Kamus Istilah Hukum, - (Terjemahan Saleh Adi Winata, et:al), Binacipta, Bandung, 1983.

2. Heuken, S.J., Adolf, Kamus Jerman Indonesia, Gramedia, Jakarta, 1987 . 